\title{
DEPOPULACIJA SJEVERNE HRVATSKE ISTRE
}

\author{
Ivan Zupanc*
}

\begin{abstract}
Izvleček
Članek se ukvarja z demografskim razvojem hrvaške Istre v obdobju 1948-1991. Poudarek je na problematiki depopulacije kot prevladujočemu pojavu. Posledica depopulacije je neugodna starostna sestava prebivalstva na večini državnega teritorija. Kot mogoča in realna perspektiva se kaže izumiranje posameznih območij.
\end{abstract}

Ključne besede: depopulacija, Istra, emigracija

\section{DEPOPULATION OF NORTERN CROATIAN ISTRA}

\begin{abstract}
This work deals with demographic development of the northern part of Croatian Istria in the period from 1948. to 1991. The main problem dealt in the article is depopulation as a dominant feature of this area. The direct consequence and indicator of depopulation is a bad age structure which prevails in the majority of this area. The extinction of particular settlements is a potential threat and imminent demographic perspective.
\end{abstract}

Key words: depopulation, Istria, emigration

* prof. geografije, Kurelčeva 4, 10000 Zagreb, Hrvatska 


\section{Uvodne i metodološke napomene}

Prostor sjevernog dijela hrvatske Istre (u daljnjem tekstu sjeverne Istre) predstavlja pogranični pojas uz granicu s Republikom Slovenijom između rijeka Dragonje i Mirne. Prema administrativno-teritorijalnoi podjeli to je prostor bivših općina Buje i Buzet (tradicionalni nazivi Bujština i Buzeština). Krajem 1992., ti. početkom 1997. godine područje je podijeljeno na 4 grada (Buje, Buzet, Novigrad i Umag) i 4 općine (Brtonigla, Grožnjan, Lanišće i Oprtali). Godine 1948. na ovom je prostoru živjelo 22,0 \% stanovništva hrvatske Istre (isti prostor koji obuhvaća županija Istarska, u daljnjem tekstu samo Istra), da bi danas (1991.) udio iznosio 15,3\%.

Upravo radi točnog utvrđivanja poznate spoznaje o depopulaciji tzv. gornje Bujštine (danas je to prostor uglavnom općina Grožnjan i Oprtali) i Buzeštine (osobito krškog i brdovitog dijela Ćićarije-općine Lanišće) kao tipičnog uzorka unutrašnje Istre s jedne strane te procesa litoralizacije ${ }^{\text {s }}$ s druge, analiza je vršena na razini novih općina/gradova i naselja. $U$ radu je korišten naseljski skup prema popisima stanovništva uz malu korekciju, naime naselja UmagKomunela i Umag te Buzet i Fontana koja su u popisima iskazivana kao samostalna, razmatrali smo kao cjelinu budući da oni doista čine funkcionalnu cjelinu na što je uostalom već i upozoreno u literaturi (Bertić, I., 1997:23, Blažević, I., 1994:544, Radica, T., 1980:165), a i službena statistika ih sada tako tretira (Imenik naselja RH, DZS, 1998, Zagreb). Dakle, analizirani naseljski skup ima 152 umjesto 154 (u međuvremenu je naseljski skup porastao na 164) naselja. Podaci su, gdje je to bilo potrebno i moguće, komparirani s cijelom Istrom.

\section{Ukupno kretanje stanovništva sjeverne Istre od 1948. do 1991. godine}

Razdoblje nakon Drugog svjetskog rata obilježeno je najintenzivnijm promjenama demografske slike ovog prostora. Uzrok poražavajuće slike je i dalje egzodus tzv. optanata (o uzrocima vidjeti: Giuricin, L., 1986:51-52; Laušić, A., 1987:371-379; Miculian, A., 1991:112-114); naime 1951. potpisan je drugi

\footnotetext{
' O toj pojavi I.Blažević zaključuje: "Proces litoralizacije, jednostavnije rečeno okupljanje života i aktivnosti uz obalu mora, dobio je nove značajne impulse ekspanzijom istarskog turizma negdje od sredine sedamdesetih godina. Litoralizacija dobrim dijelom snaži na račun unutra\{nijh dijelova polvotoka u kojima nastaju sve veće demografske praznine" (1991:8-9).
} 
sporazum o opcijama (Službeni list FNRJ, br. 1/1951 i 12/1951), a treći 1964. (ratificiran 1965.,Službeni list SFRJ-Međunarodni ugovori i drugi sporazumi (MUIDS), br. 8/1965). Iz dijela pod Zonom B iseljavanje je legalizirano Memorandumom o suglasnosti (točka 8.) potpisanim 5.10.1954. (Službeni list-MUIDS, br. 6/1954), no to ne znači da nije bilo iseljavanja jer osim opcijama i kasnije otpustom iz državljanstva iseljavalo se i ilegalno. Od 8.10.1953. do kraja kolovoza 1956. s tog je teritorija ${ }^{2}$ iseljeno 7.831 osoba (Trani, G., 1980:577). lako manje korištena, mogućnost iseljavanja putem otpusta iz jugoslavenskog državljanstva omogućena je zakonom o jugoslavenskom državljanstvu 1964. (Službeni list SFRJ, br. 38/1964) i Osimskim sporazumom od 10.11.1975. (stupio na snagu 11.3.1977., Službeni list SFRJ-Međunarodni ugovori, br. 1/1977). Prema podacima iz arhiva MUP-a koje je obradio V. Žerjavić, iz tadašnje općine Buzet 1951. godine broj opcija iznosio je 191, a iz općine Buje (nije jasno na koji se to dio odnosi jer navodi i podatak o 20.000 optanata iz Zone B) 6. Ako sada zbrojimo te podatke za cijeli prostor sjeverne Istre prema Žerjaviću broj iseljenih iznosi 22.483 (opcije iz 1948. i 1951., broj iseljenih iz hrvatskog dijela zone B i broj otpuštenih i iseljenih u Italiju do 1974. koji iznosi 441) (Žeriavić, V., 1993:642, 652-653).

Tablica 1. Stanovništvo općina/gradova sjeverne Istre 1948.-1991.

\begin{tabular}{|l|r|r|r|r|r|r|}
\hline općina/grad & 1948. & 1953. & 1961. & 1971. & 1981. & 1991. \\
\hline Brtonigla & 2892 & 1869 & 1958 & 1523 & 1446 & 1398 \\
\hline Buje & 7985 & 5759 & 5340 & 4374 & 4957 & 5421 \\
\hline Buzet & 9521 & 8838 & 7088 & 5895 & 6168 & 6295 \\
\hline Grožnjan & 3475 & 2344 & 1861 & 1078 & 914 & 854 \\
\hline Lanišće & 3235 & 2698 & 1715 & 927 & 624 & 621 \\
\hline Novigrad & 2313 & 1743 & 2094 & 2398 & 2619 & 3270 \\
\hline Oprtali & 3803 & 3186 & 2220 & 1500 & 1255 & 1109 \\
\hline Umag & 7127 & 6900 & 7558 & 8162 & 9936 & 12348 \\
\hline Sjeverna Istra & 40351 & 33337 & 29834 & 25857 & 27919 & 31316 \\
\hline Istra & 183340 & 175094 & 176838 & 175199 & 188332 & 204346 \\
\hline $\begin{array}{l}\text { Sjeverna } \\
\text { Istra/Istra (\%) }\end{array}$ & 22,0 & 19,0 & 16,9 & 14,8 & 14,8 & 15,3 \\
\hline
\end{tabular}

Izvor: od 1948.-1971. (2); za 1981. (5); za 1991. (6)

\footnotetext{
2 Podaci o izbjeglicama su objavlieni prema 5 područja (općina): Umag 2.385, Buje 2.517,
} Brtonigla 967, Novigrad 1.342, Grožnjan 620 (Trani, G., 1980:577). 
Osim iseljavanja u sklopu "istarskog egzodusa" kao uzroci depopulacije javljaju se odgođeni efekt ratnih gubitaka, naslijeđena populacijsko-naseljska struktura (1948. 54,6 \% naselja bilo je u veličinskom razredu od 0-200), koncentracija gospodarskog razvoja u općinskim centrima, prometna izoliranost pojedinih naselja, proces litoralizacije, deagrarizacija ${ }^{3}$ i ruralni egzodus koji se nastavlja i isprepliće s "istarskim egzodusom" te negativni prirodni prirast.

Razdoblje 1948.-1953. ${ }^{4}$ obilieženo je najvećim padom (17,4 \%, u cijeloj Istri smanjenje iznosi 4,5\%) apsolutnog broja stanovnika sjeverne Istre od svih međupopisnih razdoblja. Pad se nastavlja i u iduća dva razdoblja dok istovremeno broi stanovnika Istre pretežno stagnira (tabl. 2). Od 1971. do 1991. sjeverna Istra bilježi veći porast od čitave Istre (doduše razlika je 1971.1981. samo 0,5\%). Ako uspoređujemo prvi poslijeratni popis i posljednji (1991.) stanovništvo sjevernog dijela umanjeno je za $22,4 \%$ dok se u Istri povećalo za $11,5 \%$.

Tablica 2. Pokazateli promiene (indeks) broja stanovnika od 1948.-1991.

\begin{tabular}{|l|r|r|r|r|r|r|}
\hline općina/grad & $\begin{array}{r}1953 . / \\
1948 .\end{array}$ & $\begin{array}{r}1961 . / \\
1953 .\end{array}$ & $\begin{array}{r}1971 . / \\
1961 .\end{array}$ & $\begin{array}{r}1981 . / \\
1971 .\end{array}$ & $\begin{array}{r}1991 . / \\
1981 .\end{array}$ & $\begin{array}{r}1991 . / \\
1948 .\end{array}$ \\
\hline Brtonigla & 64,6 & 104,8 & 77,8 & 94,9 & 96,7 & 48,3 \\
\hline Buje & 72,1 & 92,7 & 81,9 & 113,3 & 109,4 & 67,9 \\
\hline Buzet & 92,8 & 80,2 & 83,2 & 104,6 & 102,1 & 66,1 \\
\hline Grožnjan & 67,5 & 79,4 & 57,9 & 84,8 & 93,4 & 24,6 \\
\hline Lanišće & 83,4 & 63,6 & 54,1 & 67,3 & 99,5 & 19,2 \\
\hline Novigrad & 75,4 & 120,1 & 114,5 & 109,2 & 124,9 & 141,4 \\
\hline Oprtalj & 83,8 & 69,7 & 67,6 & 83,7 & 88,4 & 29,2 \\
\hline Umag & 96,8 & 109,5 & 108,0 & 121,7 & 124,3 & 173,3 \\
\hline Sjeverna Istra & 82,6 & 89,5 & 86,7 & 108,0 & 112,2 & 77,6 \\
\hline Istra & 95,5 & 101,0 & 99,1 & 107,5 & 108,5 & 111,5 \\
\hline
\end{tabular}

Izvor: (2), (5), (6) prema podacima u tabl. 1.

${ }^{3} \mathrm{O}$ obujmu deagrarizacije neka posvjedoče podaci o udjelu poljoprivrednog stanovništva u ukupnom stanovništvu sjeverne Istre. 1961. taj je udjel iznosio $54,9 \%$ da bi 1991. pao na 6,6 \%. Najveći pad je u općini Lanišće (sa 77,0 \% na 4,7 \%), a najmanji u općini Grožnjan (sa 76,4% na 24,4 \%) (Popis stanovništva 1961., Kniiga XV, Poljoprivredno stanovništvo, SZS; Beograd, 1966; Popis stanovništva 1991., Poljoprivredno stanovništvo prema aktivnosti i spolu po naseljima, Dokumentacija 886, DZS, Zagreb, 1994.).

${ }^{4}$ Za područje tada\{njih općina Buje, Novigrad i Umag (u okviru granica kotara Buje 1948.) podaci se odnose na 25.4.1956. jer je tada izvr\{ena registracija stanovni\{tva na tom područiu (Korenčić, M., 1979:1 1). U literaturi i popisnim publikacijama već je uvriježena godina 1953. za taj prostor. 
Analizirajući situaciju po općinama/gradovima uočava se slijedeće: u periodu 1948.-1953. svi gube apsolutni broj stanovnika. Gradovi Umag i Novigrad od 1953. konstantno bilieže porast stanovništva (najveći 1981.1991., gotovo 25 \%) što je slučaj u gradovima Buje i Buzet tek od 1971. Općine Grožnjan, Lanišće i Oprtali od 1948. stalno bilieže pad. Može im se pridružiti i općina Brtonigla koja jedino od 1953.-1961. bilježi porast.

Do 1975. Umag i Novigrad su sjedišta istoimenih općina pa se stoga brže razvijaju (uz naravno proces litoralizacije). Ako promatramo prostor gradova Umag i Novigrad bez niihovih sjedišta, onda bi pad stanovništva bio zabiliežen jedino u razdoblju 1961.-1971. Naijače je izražena polarizacija 1991. kada u Umagu živi 62,5 \% stanovništva administrativno-teritorijalne jednice grada, a u Novigradu 77,1 \%. Na teritoriju gradova Buje i Buzet polarizacija u gradskim centrima iznosi 59,0 \% i 29,5 \% u 1991. (također najviše). Buzet je ostvario najveći indeks promjene udjela u stanovništvu područja grada/općine u odnosu 1948.-1991., on iznosi 398,6 \% (sa 7,4 \% na 29,5\%). Slijede ga Umag sa 233,2 \% i Buje sa 205,6 \%. Najeksplozivniji rast Buzet je ostvario od 1971.-1981. kada se njegovo stanovništvo udvostručilo (indeks 204,2).

Podaci po naseljima otkrivaju svu silinu depopulacije. Udio naselja koja depopuliraju se kreće ovako: 1948.-1953. 87,5 \%; 1953.-1961. 84,2 \%; 1961.-1971. 91,4\%; 1971.-1981. 81,6\%; 1981.-1991. 61,8\%. Odmah se vočava da je najlošije razdoblje 1961.-1971. kada 139 naselja bilježi pad apsolutnog broja stanovnika, a samo 13 ili 8,6 \% bilježi porast. Prema jednoj anketi $^{5}$ iz 1970. broj iseljenih iz tadašnje općine Buzet od 1961. do 1970. iznosio je 1.925. Najveći dio iselio se u obalna istarska naselja $(28,1 \%)$, zatim u Sloveniju (uglavnom Slovensko primorie, 25,6 \%), ostali dio Hrvatske (11,8 \%) i u Italiju (uglavnom Trst, 1 1,3 \%) (Baučić, I., 1970:64).

Gotovo polovica (točnije 46,7 \%) naselja bilježi gubitak stanovništva u svim međupopisnim razdobljima, a čak 90,8 \% ili 138 ima manje stanovnika 1991. nego 1948. Od 14 naselja koja u tom razdoblju bilježe porast 9 ih je u uskom priobalnom pojasu, dva su gradski/općinski centri (Buje i Buzet s prigradskim naseljem Sv.Martin) dok se Roč razvija kao lokalni centar (Malić, A., 1992:53).

\footnotetext{
${ }^{5}$ Anketu su proveli studenti geografije iz Zagreba i Liubljane od 25. do 29.5.1970. na području tadašnje općine Buzet (danas grad Buzet, općina Lanišće i dio općine Oprtali, op.I.Z.) (Baučić, I., 1970:52).
} 


\section{Prirodno kretanje}

Praćenje prirodnog kretanja po naseljima statistika nam omogućava tek od 1964. godine pa je stoga i time omeđena donja granica razmatranja. Od 1964. do 1970. broj naselja s negativnim prirodnim prirastom je 89 $(58,6 \%)$ dok ih 47 ili 30,9\% ima pozitivan prirodni prirast (istovremeno 16 ih ima nulti prirodni prirast). Općine Lanišće (-89), Grožnjan (-61) i Oprtali (-19) bilježe više umrlih nego rođenih.

U idućem razdobliu, od 1971.-1980., nastavlja se negativan prirodni prirast $u$ istim općinama, ali im se pridružuje i Brtonigla (tabl. 3). Broj naselja u kojima je više umrlih nego živorođenih iznosi 104 ili 68,4 \% dok ih četvrtina $(25,7 \%)$ bilježi obrnutu situaciju. Zanimljivo je da u sedam naselja nije bilo rođenih, a u 14 rodilo se samo jedno dijete.

Posljednje razdoblje (1981.-1990.) povećalo je broj naselja s negativnim prirodnim prirastom na 73,0 \% (111) i smanjilo broi u kojima je prirodni prirast pozitivan. Kao kuriozitet navodimo da u 15 ili 9,9\% naselja nije bilo rođenih, a u 21 naselju broj rođenih iznosi jedno dijete. Iste općine kao i u prethodnom periodu imaju negativan prirodni prirast (osim Brtonigle).

Tablica 3. Prirodni prirast/pad i migracijski saldo sjeverne Istre po općinama/ gradovima 1971.-1991.

\begin{tabular}{|c|c|c|c|c|c|c|c|c|}
\hline \multirow[b]{2}{*}{ općina/grad } & \multicolumn{4}{|c|}{ 1971.-1981. } & \multicolumn{4}{|c|}{ 1981.-1991. } \\
\hline & $\begin{array}{l}\bar{c} \\
\bar{d} \\
+\frac{0}{0} \\
0 \\
0 \\
i \frac{1}{N}\end{array}$ & 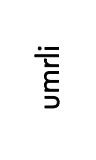 & 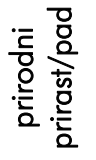 & 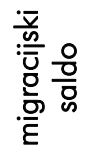 & 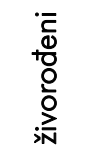 & $\begin{array}{l}\overline{\overline{\grave{k}}} \\
\overline{\mathrm{g}}\end{array}$ & 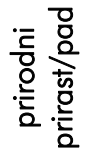 & 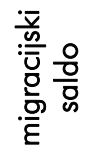 \\
\hline Brtonigla & 137 & 162 & -25 & -52 & 153 & 148 & 5 & -53 \\
\hline Buje & 730 & 602 & 128 & 455 & 986 & 709 & 277 & 187 \\
\hline Buzet & 900 & 790 & 110 & 163 & 814 & 770 & 44 & 83 \\
\hline Grožnjan & 87 & 146 & -59 & -105 & 66 & 122 & -56 & -4 \\
\hline Lanišće & 30 & 182 & -152 & -151 & 35 & 201 & -166 & 163 \\
\hline Novigrad & 395 & 208 & 187 & 34 & 350 & 284 & 66 & 585 \\
\hline Oprtali & 111 & 229 & -118 & -127 & 116 & 216 & -100 & -46 \\
\hline Umag & 1318 & 713 & 605 & 1169 & 1430 & 811 & 619 & 1793 \\
\hline Sjeverna Istra* & 3739 & 3060 & 679 & 1383 & 3966 & 3285 & 681 & 2716 \\
\hline
\end{tabular}

* razlika do ukupno odnosi se na živorođene i umrle u inozemstvu Izvor: (2), (5), (6) i (14) 


\section{Tipovi općeg kretanja stanovništva ${ }^{6}$}

Opće kretanje stanovništva stavlja u odnos prirodno i mehaničko kretanje. Primjenom ovog modela na razini općina/gradova u razdoblju 1971.-1981. zamjećuje se dvojakost. Trend izumiranja $\left(E_{4}\right)$ obiliežje je općina gornje Bujštine, Lanišće i Brtonigla dok je u ostalim gradovima trend $I_{1}$ (ekspanzija imigracijom). Uglavnom isti trendovi nastavljeni su $U$ zadnjem desetlieću (tabl. 4).

Originalniii presjek daje analiza na razini naselja. Od 1971.-1981. 97 ili $63,8 \%$ naselja je egzodusnog tipa $\left(E_{1}-E_{4}\right)$ među kojima dominiraju ona $s$ trendom izumiranja (takvih je $43,4 \%$ od svih naselja). Točno polovica tih naselja je na području grada Buzeta. Udio naselja tipa $E_{4}$ pao je $u$ zadnjem desetlieću na 40,1 \%. Istovremeno, udio imigracijskih naselja porastao je s $24,3 \%$ na $38,8 \%$.

Zanimao nas je odnos prirodnog pada i emigracije $u$ depopulaciji odnosno porastu broja stanovnika pojedinih naselja. Kod depopulacijskih naselja kojih je od 1971.-1981. 124, u 72 ili 58,1 \% (tip $\mathrm{E}_{4}$ ) zajednički djeluju negativan migraciiski saldo i prirodni pad. Pri tom je važniju ulogu imao negativan migracijski saldo jer je određivao i depopulaciju i njen intenzitet u 65,3\% naselja. U 29,8 \% ili 37 naselja intenzitet i predznak pod dominacijom je prirodnog pada. Od 27 naselja koja u tom periodu bilježe porast u njih $22 \mathrm{ga}$ generira imigracija jer je veća od pozitivnog ili negativnog prirodnog prirasta.

Posljednje desetljeće bilježi smanjenje utjecaja negativnog migracijskog salda (53,3 \% naselja) i relativno povećava udjel prirodnog pada u depopulaciji (38,3 \% naselja). Porastao je udjel zajedničkog djelovanja ovih čimbenika. Sada je on prisutan u 64,9\% naselja. Pozitivan migracijski saldo dominira i u ovom desetljeću kod naselja kojima raste broj stanovnika (takvih je 40 ili 72,7 \%) jer je veći od prirodnog/nultog prirasta, a u 31 naselju anulira utjecai prirodnog pada.

\footnotetext{
${ }^{6}$ M.Friganović izdvaja osam tipova općeg kretanja stanovništva: četiri egzodusna tipa od $E_{1}$ do $E_{4}$ koji imaju negativnu migracijsku bilancu, ali različitog intenziteta i četiri imigracijska tipa od $\mathrm{I}_{1}$

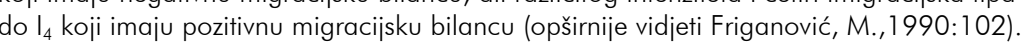


Tablica 4. Opće kretanje stanovništva sjeverne Istre od 1971.-1991.

\begin{tabular}{|l|r|r|r|r|r|r|}
\hline & \multicolumn{3}{|c|}{$1971 .-1981}$. & \multicolumn{2}{|c}{1981.1991.} \\
\hline općina/grad & $\begin{array}{r}\text { prirodni } \\
\text { prirast/pad }\end{array}$ & $\begin{array}{r}\text { ukupno } \\
\text { kretanje }\end{array}$ & $\begin{array}{r}\text { tip } \\
\text { OKS-a }\end{array}$ & $\begin{array}{r}\text { prirodni } \\
\text { prirast/pad }\end{array}$ & $\begin{array}{r}\text { ukupno } \\
\text { kretanje }\end{array}$ & $\begin{array}{r}\text { tip } \\
\text { OKS-a }\end{array}$ \\
\hline Brtonigla & -25 & -77 & $\mathrm{E}_{4}$ & 5 & -48 & $\mathrm{E}_{3}$ \\
\hline Buje & 128 & 583 & $\mathrm{I}_{1}$ & 277 & 464 & $\mathrm{I}_{1}$ \\
\hline Buzet & 110 & 273 & $\mathrm{I}_{1}$ & 44 & 127 & $\mathrm{I}_{1}$ \\
\hline Grožnjan & -59 & -164 & $\mathrm{E}_{4}$ & -56 & -60 & $\mathrm{E}_{4}$ \\
\hline Lanišće & -152 & -303 & $\mathrm{E}_{4}$ & -166 & -3 & $\mathrm{I}_{4}$ \\
\hline Novigrad & 187 & 221 & $\mathrm{I}_{1}$ & 66 & 651 & $\mathrm{I}_{1}$ \\
\hline Oprtali & -118 & -245 & $\mathrm{E}_{4}$ & -100 & -146 & $\mathrm{E}_{4}$ \\
\hline Umag & 605 & 1774 & $\mathrm{I}_{1}$ & 619 & 2412 & $\mathrm{I}_{1}$ \\
\hline Sjeverna Istra* & 679 & 2062 & $\mathrm{I}_{1}$ & 681 & 3397 & $\mathrm{I}_{1}$ \\
\hline Istra & 8972 & 13133 & $\mathrm{I}_{1}$ & 6041 & 16014 & $\mathrm{I}_{1}$ \\
\hline
\end{tabular}

* razlika do ukupno odnosi se na prirodni prirast/pad u inozemstvu Izvor: isti kao i za Tablicu 3.

Da zaključimo, u posljednja dva desetljeća depopulacija je uzrokovana prvenstveno pod utjecajem emigracije, a potom i negativnog prirodnog prirasta. U zadnjem desetljeću porast udjela prirodne depopulacije uzrokovan je procesom starenja stanovništva (vidjeti iduće poglavlje) do te miere da "više nema tko iseliti" (poznato je da iseljava uglavnom mlađe stanovništvo u dobi od 20-39 godina). Prostor obuhvaćen tim procesom ušao je u fazu izumiranja (usporediti Wertheimer-Baletić, A., 1999:273).

\section{Starenje stanovništva}

Osim vanjskih faktora (rat, prirodne katastrofe i drugi) na dobnu strukturu utječu prirodni prirast/pad i migracijska kretanja. Proces starenja stanovništva pokazateli je i posljedica depopulacije nekog prostora. Za analizu starosne strukture koristili smo indeks starosti ${ }^{7}$ koji stavlja u odnos stanovništvo starije

\footnotetext{
${ }^{7}$ Za neka naselja zbog izuzetno malih brojeva Xs je pretjerano visok npr.: Račja Vas 1.133,3 (3/34), Kropinjak 1.000 (1/10), Krkuž 1.000 (1/10), Prapoće 675 (4/27), itd. lako se kod takvih slućajeva gubi smisao izračunavanja indeksa, ipak smo ga odredili. Naselja Benčići, Blatna Vas, Brgudac, Dane, Klenovščak, Podkuk i Trstenik nemaju stanovnike u skupini 0-19 (1991.) pa smi ih također uvrstili u tip izrazito duboka starost. $U$ istoj godini naselje Vrnjak nema stanovnike u skupinama $<20$ i $>59$ pa na slici 2. nije označeno šrafurom.
} 
od 59 i mlađe od 20 godina. Upotrijebliena je kombinirana klasifikacija prema Nejašmić, I. (1991:175) koja izdvaja šest tipova stanovništva po dobnom sastavu.

Tablica 5. Indeks starosti* stanovništva sjeverne Istre 1961. i 1991.

\begin{tabular}{|c|c|c|c|c|c|c|c|c|c|}
\hline & \multicolumn{3}{|c|}{1961.} & \multicolumn{3}{|c|}{1991.} & & & \\
\hline $\begin{array}{l}\text { općina/ } \\
\text { grad }\end{array}$ & $P<20$ & $P>59$ & Xs & Tip & $\mathrm{P}<20$ & $P>59$ & Xs & Tip & $\begin{array}{c}\text { Indeks } \\
1991 \\
1961 \\
\end{array}$ \\
\hline Brtonigla & 656 & 275 & 41,9 & STA & 334 & 285 & 85,3 & DST & 203,6 \\
\hline Buje & 1742 & 744 & 42,7 & STA & 1526 & 905 & 59,3 & DST & 138,9 \\
\hline Buzet & 2337 & 1101 & 47,1 & ST & 1667 & 1265 & 75,9 & DST & 161,1 \\
\hline Grožnjan & 609 & 310 & 50,9 & ST & 178 & 240 & 134,8 & ISDT & 264,8 \\
\hline Lanišćé & 514 & 355 & 69,1 & DST & 90 & 252 & 280,0 & ISDT & 405,2 \\
\hline Novigrad & 797 & 186 & 23,3 & NST & 848 & 481 & 56,7 & DST & 243,3 \\
\hline Oprtali & 708 & 385 & 54,4 & ST & 244 & 318 & 130,3 & ISDT & 239,5 \\
\hline Umag & 2622 & 785 & 29,9 & NST & 3341 & 1755 & 52,5 & ST & 175,6 \\
\hline $\begin{array}{l}\text { Sjeverna } \\
\text { Istra }\end{array}$ & 9985 & 4141 & 41,5 & STA & 8228 & 5501 & 66,9 & DST & 161,2 \\
\hline Istra & 60167 & 21278 & 35,4 & STA & 52783 & 35551 & 67,4 & DST & 190,4 \\
\hline
\end{tabular}

$* \mathrm{X}_{\mathrm{S}}=\mathrm{P}>59 / \mathrm{P}<20 \times 100$;

ST - starost, STA-starenje, DST- duboka starost, PST-na pragu staranja, IDST-izrazito duboka staroist, NST-na pragu starenja Izvor: (3) i (7)

Primienom ove tipizacije na razini općina/gradova vočava se već 1961. nepovoljna struktura (tabl. 5). Relativno bolja struktura bila je u gradu Novigradu (na pragu starenja) koji je u okviru Istre bio na drugom mjestu iza grada Labina (usporedba na razini današnjih općina/gradova). Već je tada općina Lanišće bila nepovoljno pozicionirana u Istri (36. mjesto od 38). Pri dnu su i općine Oprtali (32.) i Grožnjan (31.). Trideset godina kasnije ove općine imaju najlošiju starosnu strukturu u cijeloj Istri (nalaze se na samom dnu, ovim redom: Lanišće, Grožnjan, Oprtalj). Pritom općina Lanišće ima drugi najveći indeks promjene indeksa starosti (1991./1961.) koji iznosi 
405,2 \% (tabl. 5). Veći indeks ima samo općina Motovun (409,3 \%). Najpovolinija situacija je u gradu Umagu (3. mjesto iza Vrsara i Poreča).

Podaci za naselja pokazuju da je 1961. samo 12 ili 7,9\% naselja tipa izrazito duboka starost. Tipu duboka starost pripadalo je 58 naselja što zajedno s prethodnim tipom iznosi $46,0 \%$ naselja. Mladost stanovništva bilo je obiliežje samo sedam naselja. Zadnjim popisom ustanovljeno je da nema naselja na sjeveru Istre koje pripada tipu mladost. Udio naselja $s$ izrazito dubokom starosti porastao je na 58,6 \% (89). Ako tai broj pridružimo kategoriii duboka starost on sada iznosi 126 ili 82,9\% naselja.

\section{Naselja slabe demografske perspektive}

Popisom 1991. utvrđeno je jedno naselje bez stalnih stanovnika. To je naselje Kotli. S obzirom na tendenciju demografskog razvoja, misleći na zamah depopulacije, bilo je zanimljivo izraditi projekciju koja će naselja izumrijeti u doglednoi budućnosti (otprilike do 2020.) i time postati "mrtva sela". Budući da su parametri samo demografski svjesni smo nedostatka ovakvog "kabinetskog istraživanja". Kriteriji su bili slijedeći:

1. Veličina naselja 1991.<30

2. 2. U razdoblju 1961.-1981. smanjenje broja stanovnika $50 \%$ i više (to je natprosječno smanjenje jer za ukupni depopulacijski skup sjeverne Istre ono iznosi $38,1 \%$ )

3. U razdoblju 1981.-1991. smanjenje broja stanovnika $20 \%$ i više (za ukupni depopulaciijki naseljski skup sjeverne Istre iznosi 14,8 \%)

4. Prirodni pad u razdobliu 1981.-1991.

5. Udio mladih (0-19) $\leq 15 \%$ ili ako ih vopće nema

Napomena: za patuljasta naselja (do 15 stanovnika) dopustili smo da jedan kriterij ne zadovoljavaju (takvih je tri), a za naselja s više od 15 stanovnika (ali naravno do 30) "olabavili" smo jedan kriterii ako u posljednja dva desetljeća (1971.-1981. i 1981.-1991.) imaju tip općeg kretanja stanovništva $\mathrm{E}_{4}$ (izumiranje) (takva su dva).

Upotrebom ovog modela prepoznali smo 16 naselja "crne" demografske perspektive. To su rubna naselja ovog prostora. U općini Lanišće: Brgudac, Dane, Jelovice, Klenovšćak, Kropinjak, Rašpor i Trstenik; u gradu Buzet: Benčići, Blatna Vas, Podkuk, Seljaci; u gradu Buje: Brdo, Brič, Kućibreg i Lozari te Vrnjak u općini Grožnjan. 


\section{Zaključak}

Nakon drugog svjetskog rata ukupan prostor zahvaćen je snažnom depopulacijom koja traje do 1971., unatoč činjenici da priobalni prostor (gradovi Novigrad i Umag) konstantno bilieži porast već od 1953. U razdobliu 1961.-1971. čak je 91,4 \% ili 139 naselja depopuliralo. Usporedba početka (1948.) i kraja (1991.) analiziranog poslijeratnog razdoblja otkriva da je u 138 ili 90,8 \% naselja smanjen broj stanovnika, a da gotovo polovica naselja $(46,7 \%)$ bilieži pad u svim međupopisnim razdobljima od 1948. do 1991. Proces depopulacije smanjen je u razdoblju 1971.-1981. na 81,6\% naselja i osobito od 1981. do 1991. (61,8 \%), ali u depopulaciii naselja raste relativan udio prirodnog pada, a smanjuje se udjel emigracije, uz starenje stanovništva što znači da je depopulacija ušla u posliednju fazu; fazu izumiranja stanovništva. Izravna posljedica i pokazateli depopulacije jest starenje stanovništva. Zadnji popis iz 1991. ustanovio je da čak 82,9\% naselja ima duboko staro ili izrazito duboko staro stanovništvo.

Može se pretpostaviti da će depopulacija sve manje biti uzrokovana emigracijom; glavnim uzrokom nakon drugog svjetskog rata do danas (1991.), a sve više prirodnim padom uz istovremeno daljnje starenje stanovništva. Mnoga će se naselja ugasiti (prepoznali smo ih 16) i time postati puki geografski pojmovi kao što se to u međuvremenu dogodilo s naseljem $V_{\text {rnjak }}{ }^{8}$.

\section{Literatura i izvori}

Baučić, Ivo (1970): Suvremena demografska kretanja u Buzeštini i njihove gospodarske posliedice, Istarski mozaik, br. 5-6, str. 51-67.

Bertić, Ivan (1997): Istra-geografska obilježja, Geografski horizont, br. 2, str. 11-34.

Blažević, Ivan (1991): Demografske značajke Istre, Gospodarstvo Istre, br. 4, str. 7-15.

Blažević, Ivan (1994): Demografski aspekt urbanih središta Istarske Županije, Zbornik radova znanstvenog skupa "Susreti na dragom kamenu", sv. 19, str. 541-552.

\footnotetext{
8 Terenskim obilaskom 13.8.1994. i 4.4.1999. utvrdili smo da je naselje Vrnjak bez stalnih stanovnika. Postalo je "mrtvo selo".
} 
Friganović, Mladen (1990): Demogeografija: stanovništvo svijeta, Zagreb, Školska knjiga.

Giuricin, Luciano (1986): Bez sustezanja o "povijesti jednog iseljavanja" (prev. Mario Barak), Dometi, br.4, str. 47-56.

Korenčić, Mirko (1979): Naselja i stanovništvo SR Hrvatske 1857-1971, Zagreb, JAZU (Diela JAZU, knj. 54).

Laušić, Ante (1987): Uzroci i oblici iseljavanja iz Istre nakon drugog svjetskog rata, Zapošljavanje i udruženi rad, br. 3, str. 369-387.

Malić, Adolf (1992): Centralne funkcije naselja unutrašnje Istre, Acta geografica Croatica, vol. 27, str.49-57.

Miculian, Antonio (1991): Historiografija i publicistika o egzodusu: kritička opažanja, Pazinski memorijal, sv. 22, str. 109-119.

Nejašmić, Ivica (1991): Depopulacija u Hrvatskoj: korijeni, stanje, izgledi, Zagreb, Institut za migracije i narodnosti, Globus

Radica, Tonko (1980): Prilog demografskoj valorizaciji naselja u prostornom planiranju i uređenju na primieru Istre, u: Spomen zbornik proslave 30. obljetnice Geografskog društva Hrvatske, Zagreb, GDH, str. 161-172.

Trani, Germano (1980): Problemi di quantificazione del fenomeno dell esodo, u: Storia di unesodo (grupa autora), Trieste, Istituto regionale per la storia del movimento di liberazione nel Friuli-Venezia Giulia, str. 565-577.

Wertheimer-Baletić, Alica (1999): Stanovništvo i razvoi, Zagreb, Mate d.o.o.

Žerjavić, Vladimir (1993): Doseliavanja i iseljavanja s područija Istre, Rijeke i Zadra u razdobliu 1910-1971., Društvena istraživanja, br. 4-5, str. 631-656.

Imenik naselja Republike Hrvatske, Zagreb, DZS, 1998.

Korenčić, Mirko (1979): Naselja i stanovništvo SR Hrvatske 1857-1971, Zagreb, JAZU (Djela JAZU, knjiga 54)

Popis stanovništva 1961., knjiga XI, Pol i starost, SZS, Beograd, 1965.

Popis stanovništva 1961., knjiga XV, Poljoprivredno stanovništvo, SZS, Beograd 1966.

Popis stanovništva, domaćinstava i stanova 1981., Stanovništvo po naseljima, općinama i zajednicama općina, Dok. 553, RZS SRH, Zagreb, 1984.

Popis stanovništva 1991., Stanovništvo prema narodnosti po naseljima, Dokumentacija 881, DZS, Zagreb, 1992.

Popis stanovništva 1991., Stanovništvo prema spolu i starosti po naseljima, Dokumentacija 882, DZS, Zagreb, 1994.

Popis stanovništva 1991., Poljoprivredno stanovništvo prema aktivnosti i spolu po naseljima, Dokumentacija 886, DZS, Zagreb, 1994. 
Službeni list FNRJ, br. 1/1951 i 12/1951

Službeni list FNRJ-MUIDS, br. 6/1954

Službeni list SFRJ, br. 38/1964

Službeni list SFRJ-MUIDS, br. 8/1965

Službeni list SFRJ-MU, br. 1/1977

Tabele rođeni i umrli po naseljima od 1964-1991, RZS SRH, Zagreb

\section{DEPOPULATION OF NORTERN CROATIAN ISTRA}

\section{Summary}

The aim of the article is to evaluate the demographic development of northern part of Croatian Istria and stating the intensity and the spreading of depopulation and its consequences.

After the World War II the whole area has been under a widespread depopulation which ended in 1971. The share of settlements which have undergone depopulation is: 1948.-1953. 87,5\%; 1953.-1961. 84,2 \%; 1961.-1971. 91,4\%; 1971.-1981. 81,6\%; 1981.-1991. 61,8\%. Nearly the majority $(46,7 \%)$ of settlements loses its inhabitants in all the periods between the censuses.

During depopulation of the settlements, the relative number of negative population growth increases, while the percentage of emigration decreases along with the ageing of the population which means that depopulation has reached the phase of the population dying out.

Disarranged age structure appears as the direct consequence and an indicator of depopulation. The last census from 1991. shows that $82,9 \%$ of the settlements belongs to the category of extremly very old or very old population.

It is assumed that depopulation will be caused by emigration to a much lesser extent, which was the main cause of depopulation since the end of the World War II, and much more by negative population growth along with the further ageing of the inhabitants. Many settlements will die out (we have recognized 16) and therefore become solely geographical terms. 


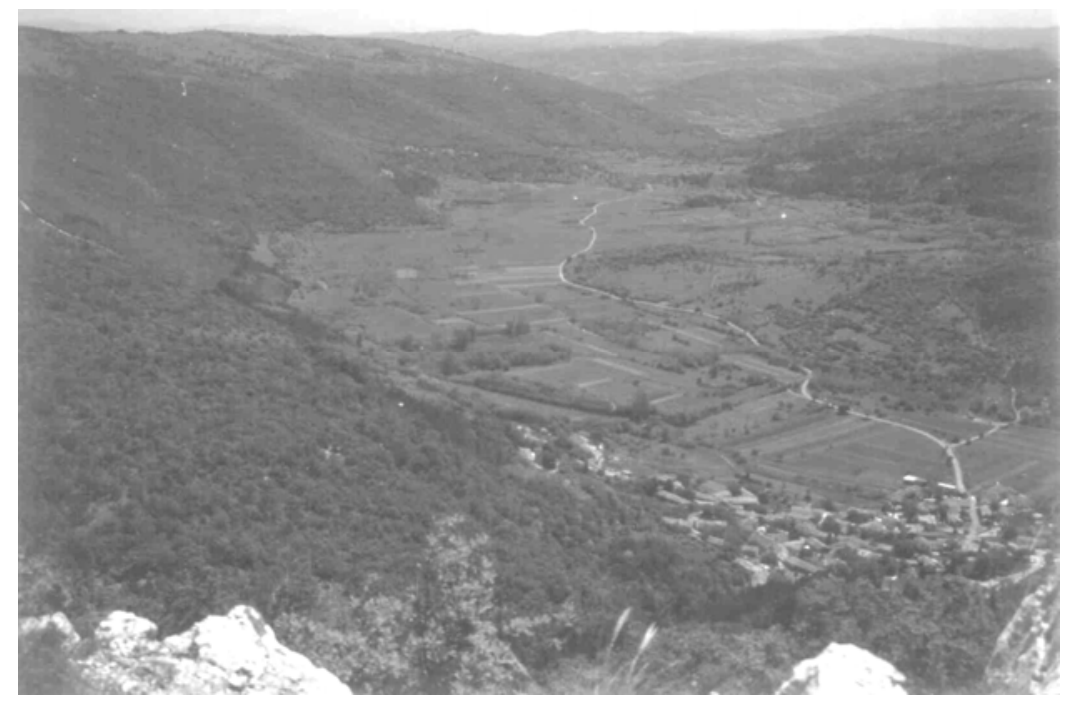

SI.4: Flišni (lapornati) svet med apnenčastimi luskami je zaradi slabše erozijske odpornosti znižan. Nastala so fluviokraška podolja, ki jim domačini pravijo »vale«. Ene spominjajo na suhe doline, druge, kot npr. Movraška vala na sliki, pa na kraška polja. Podolja so bila zaradi ugodnejših talnih razmer in izvirov, ki prihajajo na dan na stiku apnenca in fliša, ugodna za poselitev, zato so $v$ njih nastale praktično vse vasi na prehodu kraškega v flišni del Slovenske Istre. (foto: D. Ogrin) 